\title{
Developing mathematical literacy test with context of Bugis-Makassar local wisdom for junior high school students
}

\author{
Nursakiah *, Fathrul Arriah, Surya Dharma \\ Mathematics Education Department, Universitas Muhammadiyah Makassar, South Sulawesi, \\ Indonesia \\ *Correspondence: nursakiah@unismuh.ac.id \\ (C) The Author(s) 2022
}

\begin{abstract}
Various studies on the development of mathematical literacy tests have not shown any research that focuses on developing mathematical literacy tests using the context of Bugis-Makassar local wisdom with Classical Test Theory (CTT). Thus, this study aimed to produce mathematical literacy tests using the context of Bugis-Makassar local wisdom based on CTT for junior high school students through development research using ADDIE design. The development of the test integrates mathematical literacy and local wisdom elements of Bugis-Makassar. There were 15 multiple-choice items developed and tested on 33 males and 68 females at seventh-grade junior high school students. The trial involved two schools in Makassar City using a convenience sampling technique. The test kit was validated by three mathematicians and produced an Aiken index score in the range of 0.67 to 0.89 . The empirical data from the trial results were analyzed using CTT assisted by ITEMAN 4.3 software. The test analysis showed an average category for reliability test scores. As many as $47 \%$ of the items were in the medium category, and the rest were in the fair category. Meanwhile, $93 \%$ of the items have a good discriminatory ability, and $67 \%$ have distractors that were not functioning properly, then the tests items must be revised.
\end{abstract}

Keywords: Bugis-Makassar local wisdom; mathematical literacy; mathematics test

Received: 2 October 2021 | Revised: 18 October 2021

Accepted: 2 November 2021 | Published: 6 January 2022 


\section{Introduction}

Mathematical literacy is part of the 21st-century abilities that students should have. This ability refers to the skills needed to solve real-world problems (Lange, 2003). It helps each relate mathematical knowledge to the context of everyday life and use it as a basis for consideration and decision-making needed by society (OECD, 2010). In addition, the process of mathematical literacy skills involves problem-solving, assessment, communication, critical thinking, and creative processes (Taskin \& Tugrul, 2014). Two of these processes are part of long-held 21st-century competencies.

The mathematical literacy of Indonesian students is still in the low category (Irianto $\&$ Febrianti, 2017). They reviewed the results of PISA (Program for International Student Assessment) as a measure of international level for mathematical literacy skills are relevant to 21st-century skills (Pratiwi, 2019). Indonesian students have a range that is very far from expectations. The results of PISA 2018 clearly show that the tendency of Indonesian students is weak in mathematics. Indonesia is ranked 72 out of 78 countries that participate in PISA. Indonesia only outperforms the Philippines in terms of the characteristics of the same country (Totok, 2019).

As they respond to Indonesian students' low mathematical ability, they need an indepth understanding of mathematical content. Understanding mathematical content can be improved through practice tests relevant to measuring the ability (Achmetli et al., 2018). The test is proven to improve understanding (Aziza, 2019; Hamidi et al., 2018), such as questions that require them to find solutions to problems in the real world (Achmetli et al., 2018). However, mathematics teachers in Makassar City experience obstacles in preparing cognitive tests, especially identifying levels and indicators of various mathematical abilities (Batari, 2017). As a result, in the cognitive assessment of students, the teacher takes items from the book without adjusting to the ability to be measured-however, the teacher only the number of the question (Batari, 2017). Thus, the questions used by the teacher cannot measure the actual abilities of students.

Several test development studies integrate mathematical literacy with local wisdom by recognizing the role of tests in measuring and improving students' mathematical literacy. Kaunang et al. (2018) have developed items to measure mathematical literacy at the junior high school level, integrated with Minahasa local wisdom. Saukiyah et al. (2017) also developed a mathematical literacy test for junior high schools in the context of Madurese ethnic wisdom. According to Pranata et al. (2020), integrating local wisdom with mathematical literacy will enhance students' understanding. However, the tests developed by Kaunang et al. (2018) and Saukiyah et al. (2017), specifically on the coverage of Minahasa wisdom in North Sulawesi and Madurese ethnicity in East Java and has not gone through item analysis. In this regard, the test is less relevant to the contextual life of students in other areas, including South Sulawesi. The sources referring to the mathematical literacy test in the context of local wisdom in South Sulawesi are still very rarely found. At the same time, students in South Sulawesi need mathematical literacy tests in South Sulawesi local wisdom to measure and practice tests to improve 
their abilities. Bugis-Makassar wisdom from South Sulawesi has a high potential to integrate local wisdom mainly related to mathematics (Muslimin \& Rahim, 2021; Pathuddin \& Raehana, 2019).

The items in the assessment test must pass item analysis (Bichi, 2017; Herkusumo, 2011) so that it is feasible and qualified to measure students' abilities (Vincent \& Shanmugam, 2020; Sa'idah et al., 2019). Item analysis can be done with Classical Test Theory (CTT) and Item Response Theory (IRT). CTT offers convenience and suitable correspondents, while IRT requires a large sample and must meet various prerequisite tests (Istiyono, 2018). Besides that, classical test theory uses more straightforward mathematical procedures (Bichi, 2017).

From the various studies previously mentioned, it appears that none of the research focuses on the development of mathematical literacy tests using the context of BugisMakassar local wisdom with CTT. Therefore, the purpose of this study is to develop and produce a mathematical literacy ability test in the context of Bugis-Makassar local wisdom based on CTT analysis for junior high school students. This study can be used as the reference for a mathematical literacy test in the context of Bugis Makassar local wisdom, which later can be used by teachers and other researchers to measure mathematical literacy skills.

\section{Methods}

This research and development (R\&D) were conducted with five stages: Analysis, Design, Development, Implementation, and Evaluation. The selection of the model considers the steps of systematic development based on the theoretical design of learning (Tegeh \& Pudjawan, 2015).

In the analysis stage, the researcher analyzed the need for mathematical literacy tests in the context of Bugis-Makassar local wisdom through interviews with four mathematics teachers in Makassar City; identified essential competencies and local wisdom of Bugis-Makassar; arranged test objectives; determined the form of the test and the length of the test; and analyzed ethnomathematics in local wisdom of Bugis-Makassar. Some elements of Bugis-Makassar local wisdom integrated into the test: library heritage, handicrafts, traditional food, traditional games, traditional parties, traditional dances, historical buildings, Bugis-Makassar proverbs, etc. speech arts, and the name of GowaMakassar kings. Furthermore, the researcher designed a test prototype at the design stage and prepared a test grid. The test designed in this study was a multiple-choice test because it offers high reliability compared to other forms of tests. It can measure the achievement of complex learning outcomes and covers a wide range of materials (Supatmi, 2021). In addition, the items can measure the mastery of the material and the firmness of the students' stance in taking the test because of the presence of distractors (Wartoni \& Benjamin, 2020). Table 1 presents a grid of test instruments that were developed, including indicators and the distribution of questions. 
Table 1. Mathematical literacy test grids in the context of Bugis-Makassar local wisdom

\begin{tabular}{|c|c|c|c|}
\hline Basic Competence & Indicator & $\begin{array}{c}\text { Item } \\
\text { Number }\end{array}$ & Score \\
\hline \multirow{3}{*}{$\begin{array}{l}\text { 4.1 Problems } \\
\text { related to the order } \\
\text { of several integers } \\
\text { and fractions } \\
\text { (ordinary, mixed, } \\
\text { decimal, percent) } \\
\text { with the nuances of } \\
\text { Bugis-Makassar } \\
\text { Local Wisdom }\end{array}$} & $\begin{array}{l}\text { Solving the problem of the sequence of } \\
\text { fractional numbers (ordinary and } \\
\text { decimal) with the nuances of the royal } \\
\text { heirlooms of Gowa-Makassar }\end{array}$ & 1 & 1 \\
\hline & $\begin{array}{l}\text { Solving the problem of the sequence of } \\
\text { ordinary fractions and mixed numbers } \\
\text { with Makassar traditional cap nuances }\end{array}$ & 2 & 1 \\
\hline & $\begin{array}{l}\text { Sort some whole numbers and fractions } \\
\text { (ordinary, mixed, percent) with } \\
\text { traditional food nuances }\end{array}$ & 3 & 1 \\
\hline \multirow{3}{*}{$\begin{array}{l}4.2 \text { Solving } \\
\text { problems related to } \\
\text { arithmetic } \\
\text { operations of } \\
\text { integers and } \\
\text { fractions with } \\
\text { nuances of Bugis- } \\
\text { Makassar Local } \\
\text { Wisdom }\end{array}$} & $\begin{array}{l}\text { Being able to solve arithmetic operations } \\
\text { problems on integers nuanced in } \\
\text { traditional games/traditional ceremonies }\end{array}$ & 4,5 & 2 \\
\hline & $\begin{array}{l}\text { Being able to solve arithmetic operations } \\
\text { problems on fractions with nuances of } \\
\text { traditional games/traditional ceremonies }\end{array}$ & 6,7 & 2 \\
\hline & $\begin{array}{l}\text { Solving problems related to counting } \\
\text { operations with integers and fractions } \\
\text { with nuances of historical } \\
\text { buildings/traditional games/traditional } \\
\text { musical instruments/traditional } \\
\text { ceremonies }\end{array}$ & $\begin{array}{c}8,9,10 \\
11\end{array}$ & 4 \\
\hline \multirow{3}{*}{$\begin{array}{l}4.3 \text { Solving } \\
\text { problems related to } \\
\text { numbers in the } \\
\text { form of positive } \\
\text { and negative } \\
\text { integers with } \\
\text { nuances of } \\
\text { Makassar Bugis } \\
\text { Local Wisdom }\end{array}$} & $\begin{array}{l}\text { Solving number problems in the form of } \\
\text { numbers with positive integers nuanced } \\
\text { in Bugis proverbs/speech arts }\end{array}$ & 12,13 & 2 \\
\hline & $\begin{array}{l}\text { Solving number problems in the form of } \\
\text { negative integers with nuances of } \\
\text { Makassar proverbs }\end{array}$ & 14 & 1 \\
\hline & $\begin{array}{l}\text { Solving number problems in the form of } \\
\text { positive and negative integers with the } \\
\text { nuances of King of Gowa-Makassar }\end{array}$ & 15 & 1 \\
\hline
\end{tabular}

In the development stage, the researchers developed questions designed in the previous stage. There were 15 multiple-choice items developed. At this stage, validation of the questions involved three experts in mathematics education. Content validation is the essential step in test development (Widodo et al., 2021), and at least it is validated by three relevant experts (Retnawati, 2016). Validation of test items using content validation with $\mathrm{V}$ Aiken analysis. The limits on the value of Aiken accepted are from the medium to the high category or 0.4 to 1 (Retnawati, (2016).

At the implementation stage, the questions that had been validated were then tested on 68 females and 33 males at seventh-grade junior high school students in two schools at Makassar City. The fifteen questions were used as data collection instruments to get responses from students. The researchers selected two schools based on convenience 
sampling technique, namely free sample selection based on the wishes of the researcher to facilitate data collection during the COVID-19 pandemic. According to Widodo and Solehudin (2021), this technique will make it easier for researchers according to samples' availability and sample characteristics' suitability without statistical calculations. Researchers only consider specific practical criteria such as geographical proximity, ease of access, availability of samples at the location, and availability (Farrokhi \& MahmoudiHamidabad, 2012).

After getting students' responses, this development research entered the evaluation stage (evaluation). The researchers analyzed the test items using the CTT approach to get the characteristics of the items. The CTT analysis was chosen because this analysis is relevant to measurements with small respondents (100s of samples), and the analysis is simple (Istiyono, 2018). Data analysis was assisted by ITEMAN 4.3, which formed in test reliability scores and item characteristics, including item difficulty index, discrimination power, and distractor.

\section{Results}

The results were obtained during the development stage of mathematical literacy tests in the context of Bugis-Makassar local wisdom. Here, the researcher describes the results of the development of the tests carried out.

\section{Analysis Stage}

In the analysis phase, the researcher has interviewed four junior high school teachers in Makassar City. The results of these interviews are:

One of the transcripts of an interview with junior high school teachers in Makassar City is related to questions to measure computational thinking skills and plans for developing questions.

Researcher : Have you prepared questions to measure students' mathematical literacy skills? Were those questions developed/taken from books/internet/or modification of existing questions?

Teacher 1 : Never.

Teacher 2 : Not yet, so far, the ability measured more general, namely the learning outcomes. The questions were taken from books and the internet.

Teacher 3 : Maybe it was, but it was not too specific to mathematical literacy, but the goal was to measure students' mathematical understanding. The questions were taken from a collection of questions that I modified from books and worksheets.

Teacher 4 : Not yet. So far, they had only given questions for daily evaluation.

Researcher : What is your opinion if the instrument for measuring mathematical literacy skills is made in the context of BugisMakassar local wisdom, especially for seventh-grade of junior high school? 
Teacher 1 : It is great, Nak (kid), because it can preserve the local wisdom of Bugis-Makassar, especially today's children rarely know about ancestral culture and traditions.

Teacher 2 : I strongly agree and support that those students should be given contextual learning such as questions related to our culture so that they feel that mathematics is close to our lives.

Teacher 3 : Of course, I agree. It can help mathematics teachers to measure students' mathematical abilities that have rarely been known.

Teacher 4 : Please arrange them because teachers need an overview of questions that have a cultural and mathematical context. Later, the questions will be taken from textbooks and questions compiled by researchers.

The interview results showed that teachers and students required mathematical literacy tests in South Sulawesi local wisdom, especially "Bugis-Makassar." Furthermore, the identification of learning outcomes of mathematics learning material on integers and fractions for the seventh-grade junior high school in odd semesters that will be developed, namely 4.1 Solving problems related to the sequence of several integers and fractions (standard, mixed, decimal, percent), 4.2 Solving problems related to arithmetic operations with whole numbers and fractions, 4.3 Solving problems related to numbers in the form of positive and negative integer powers. The purpose of developing the test was to produce a mathematical computational thinking test in Bugis-Makassar local wisdom. At this stage, an analysis was carried out on several reference articles that reviewed ethnomathematics and Bugis Makassar local wisdom to obtain elements of local wisdom that are integrated into the problem.

\section{Design Stage}

After analyzing the needs in the field, determine the learning outcomes and elements of local wisdom that will be integrated into the problem. We began to focus on designing a test prototype, starting from determining the form of a multiple-choice test with 15 items and compiling the test grid presented in table 1. The fifteen questions are integrated with local Bugis-Makassar wisdom in the form of heirlooms from the kingdom of Gowa (Makassar), Makassar traditional caps, traditional food, traditional games, traditional party processions, regional dances, historical buildings, Makassar Bugis proverbs, musical instruments, and the kings of the Gowa kingdom and speech arts. Next, the researchers look for pictures of each local wisdom to make the questions easy to understand and look interesting for students.

\section{Development Stage}

The development stage began by writing 15 mathematics questions that are integrated with local wisdom. Here are some questions that contain elements of local BugisMakassar wisdom: 
Number 1 (Elements of the heirlooms of the Gowa-Makassar Kingdom)

Figure 1. Salokoa (royal crown of Gowa)

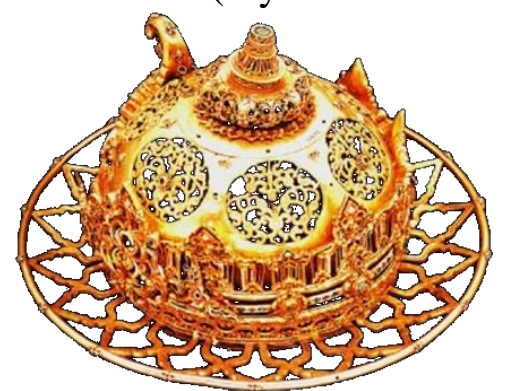

1. Saloko (slokoa) is the crown of Gowa made of diamonds, gold, silver, gems, and platinum. If the weight of the diamond $\frac{1}{5} \mathrm{~kg}$, gold $0.3 \mathrm{~kg}$, silver $\frac{2}{3} \mathrm{~kg}$, gems $0.25 \mathrm{~kg}$, and platinum $\frac{3}{5} \mathrm{~kg}$. So the heaviest element is....
a. Diamond
d. Gemstone
b. Gold
e. Platinum
c. Silver

Answer: c

\section{Number 12 (Bugis Proverb)}

12. "Iapa nakulle taue mabbaine narekko naulleni magguli-lingiwi dapurenge wekka pitu" "(aiap nkuel tauea mbaien nerko nauelni mguli-liGiwi)"is a Bugis proverb about marriage advice. Baco plans to get married at the 20 years old. However, after getting advice from the Bugis proverb, he finally decides to postpone his marriage $2^{3}$ year. If Baco's age is $4^{3}$, then his marriage age is ... years.
a. 38
d. 32
b. 36
e. 30
c. 34

Answer: $b$

Fifteen items assembled into a mathematical literacy test in Bugis Makassar local wisdom were validated by three mathematicians. Based on the value of V Aiken in Table 2 , the 15 items were valid for testing.

Table 2. The results of the content validity analysis with V-Aiken

\begin{tabular}{cccccc}
\hline Item & $\begin{array}{c}\text { V-Aiken } \\
\text { Index }\end{array}$ & Category & Item & $\begin{array}{c}\text { V-Aiken } \\
\text { Index }\end{array}$ & Category \\
\hline 1 & 0.78 & valid & 9 & 0.89 & valid \\
\hline 2 & 0.89 & valid & 10 & 0.78 & valid \\
\hline 3 & 0.89 & valid & 11 & 0.89 & valid \\
\hline 4 & 0.80 & valid & 12 & 0.89 & valid \\
\hline 5 & 0.78 & valid & 13 & 0.89 & valid \\
\hline 6 & 0.67 & valid & 14 & 0.89 & valid \\
\hline 7 & 0.78 & valid & 15 & 0.78 & valid \\
\hline 8 & 0.89 & valid & & & \\
\hline
\end{tabular}




\section{Implementation Stage}

The researchers conducted the implementation stage to get responses from students. The data was used to analyze the characteristics of the test items to see whether they were good or needed to be revised. The trials were done on students who have received whole numbers and fractions material. The researchers considered the ease of data collection during the COVID-19 pandemic, so the researchers chose two schools in Makassar City at the seventh-grade junior high school level at the odd semesters. The two schools are geographically close to the researchers' university.

\section{Evaluation Stage}

The last stage was the analysis of items based on students' responses which produced dichotomous data (scores 1 and 0 ). The researchers analyze test items using the classical test theory (CTT) approach to see the characteristics of items assisted by ITEMAN 4.3, which produces test reliability scores, and item characteristics include item difficulty index, discriminatory power, and distractors.

\section{Reliability}

The reliability value obtained from the ITEMAN 4.3 software output was 0.64 , which is in the medium category. Therefore, the mathematical literacy test in the context of BugisMakassar local wisdom is reliable.

\section{Characteristics of questions}

\section{Item difficulty level}

The item difficulty level is categorized as complex, fair, and straightforward. If it is more than 0.30 , it is categorized as complex, 0.30 to 0.70 is categorized as fair, and more than 0.70 is categorized as easy (Mardapi, 2017). The results of the analysis of the difficulty index of the mathematical literacy test items in the context of local wisdom of BugisMakassar were presented in Table 3.

Table 3. Test item difficulty level

\begin{tabular}{cccc}
\hline Category & $\begin{array}{c}\text { Number of } \\
\text { items }\end{array}$ & No item test instrument & percentage \\
\hline Difficult & & - & \\
\hline Fair & 7 & $1,4,6,9,11,14,15$ & $47 \%$ \\
\hline Easy & 8 & $2,3,5,7,810,12,13$ & $53 \%$ \\
\hline
\end{tabular}

Based on the Table 3 above, information is obtained that the items are in the easy to fair category.

\section{Discriminatory ability}

Discriminatory ability in this study by reviewing the correlation index biserial. Terms of good discriminatory ability if more than 0.3 . If it is less than this value, the test is less effective at differentiating the level of ability of students (Vincent \& Shanmugam, 2020). Based on the Table 4 below, information was obtained that there are 14 items or $93 \%$ of 
the items in the developed instrument were in the accepted category, 1 item or $7 \%$ of the items in the developed test instrument were in the revised category, and $0 \%$ of the items were in the rejected category.

Table 4. Test item discrimination power

\begin{tabular}{ccccc}
\hline Range & category & $\begin{array}{c}\text { Number } \\
\text { of items }\end{array}$ & No item test & percentage \\
\hline Pbis $>0.30$ & accepted & 14 & $\begin{array}{c}1,2,3,4,5,6,7,8,9, \\
10,11,13,14,15,\end{array}$ & $93 \%$ \\
\hline Pbis $0.10-0.30$ & revised & 1 & 12 & $7 \%$ \\
\hline Pbis $<0.10$ & rejected & & - & \\
\hline
\end{tabular}

\section{Distractor}

The distractor or distractor effectiveness can be said to be functioning if each option answers at least $5 \%$ of the test takers. If a distractor is not functioning correctly, a revision is made (Vincent $\&$ Shanmugam, 2020). The results of the calculation of the effectiveness of the distractor test instrument developed and assisted by the ITEMAN 4.3 program are presented in table 5 .

Table 5. Distractor test item

\begin{tabular}{cccc}
\hline Proportion & Category & Number of items & percentage \\
\hline 0.05 & Works well & 5 & $33 \%$ \\
\hline$<0.05$ & Not working & 10 & $67 \%$ \\
\hline
\end{tabular}

\section{Discussion}

The development of mathematical literacy questions in the context of Bugis Makassar local wisdom was carried out in 5 stages, namely: analysis, design, development, implementation, and evaluation. In the early stages of the analysis, the researchers found that the teacher had not measured students' mathematical literacy skills and tended to measure learning outcomes, in general, using questions from books, the internet, and modified ones. This reality has already been revealed by Yansa and Retnawati (2021) and Batari (2017) that the teacher takes questions from books and changes the numbers without adjusting the ability to be measured. Based on the needs analysis, the teacher strongly supports the development of mathematical literacy tests in the context of Bugis Makassar local wisdom because it supports contextual learning and makes students feel that mathematics is a part of their lives. It is in line with Lestariningsih \& Lutfianto (2021), who states that local wisdom in mathematical literacy problems helps form concepts and helps them transform problems in real life into mathematical symbols or mathematization. For this reason, researchers chose Bugis-Makassar local wisdom because of its availability of the reference to the results of ethnomathematical studies on the Bugis-Makassar tribe, which accessible like traditional food (Pathuddin \& Raehana, 2019) and traditional games of Bugis Makassar (Muslim \& Rahim, 2019).

Based on the responses from the implementation phase to students in two schools in the form of dichotomous data ( 0 and 1$)$, it was found that the characteristics of the mathematics test items in the context of the local wisdom of mathematics were developed. 
Ten questions have a low distractor because they are not functioning well. The distractor activity can bork if each option answers at least 5\% of the test takers (Vincent \& Shanmugam, 2020). If the distractor was not functioning correctly, the corrections are made to the distractor according to the suggestions of Vincent and Shop anmugam (2020). Thus, a distractor revision was made to 10 questions.

There was 1 question was easiest in terms of item difficulty level, namely question number 12. In addition, question number 12 also has low discrimination power, or its pbis value is in the range of 0.30 to 0.70 (Vincent \& Shanmugam, 2020). Easy test items can be explained as a result of the large number of test-takers choosing the correct answer, and vice versa (Bichi, 2017; Mariyati \& Affandi, 2016) because item difficulty was simply the proportion of examinees taking the test, who got the item or answered it correctly. The higher the percentage of getting the item correct, the easier the item will be. From the item difficulty index value, item 12 was the most accessible item with a value of 0.90. It can be explained that 91 students answered correctly on item 12 with an indicator of solving number problems in positive integers. According to Mardapi (2017), if the difficulty value is more than 0.70 , it is categorized as easy. However, the item that is considered difficult is item 6 , with a difficulty index value of 0.30 , showing that 31 students out of 101 test-takers answered correctly (indicator: solving fractional arithmetic operations problems with traditional game nuances). It shows that students still do not fully understand counting fractions.

After revising questions number 12 and 10, the tests produced in this development met the criteria for good test items in terms of validity, difficulty level, discriminatory ability, and distractors. So that the items that are developed, met the analysis of the characteristics of the items can be used as a practice test to improve mathematical literacy skills for students in the South Sulawesi area and provide an overview of the use of mathematics in real-world contexts.

\section{Conclusion}

This development study produces 15 items of mathematical literacy in the context of Bugis-Makassar local wisdom that was valid, reliable, and has good item characteristics. The developed math problems consisted of one on library heritage, one on handicrafts, one on traditional food, three on traditional games, two on traditional parties, one on traditional dance, one on the historic building, two on Makassar-Bugis proverbs, one on speech art, and one on the king of Gowa-Makassar. Teachers or other researchers can use mathematical literacy tests in the context of Bugis-Makassar local wisdom to measure students' mathematical literacy skills in mathematics. Based on the findings obtained, it is necessary to conduct further research on the development of questions in local wisdom integrated with other mathematics abilities to enhance the students' mathematical understanding in solving mathematical problems. 


\section{Conflicts of Interest}

The authors declare that no conflict of interest regarding the publication of this manuscript. In addition, the ethical issues, including plagiarism, misconduct, data fabrication and/or falsification, double publication and/or submission, and redundancies have been completely by the authors.

\section{References}

Achmetli, K., Schukajlow, S., \& Rakoczy, K. (2018). Multiple solutions for real-world problems, experience of competence and students'students' procedural and conceptual knowledge. International Journal of Science and Mathematics Education, 17(8), 1605-1625. https://doi.org/10.1007/s10763-018-9936-5

Aziza, M. (2019). Students' problem-solving abilities in solving closed and open questions on the subject of the circle. Pythagoras: Journal of Mathematical Education, 14(2), 126-138. https://doi.org/10.21831/pg.v14i2.26563

Batari, T. (2017). Pengembangan instrumen tes untuk mengukur kemampuan koneksi matematis mata pelajaran matematika di SMPN 17 Makassar [Development of a test instrument to measure the mathematical connection ability of mathematics subjects at SMPN 17 Makassar] [Undergraduate Thesis, UIN Alauddin Makassar]. http://repository.uin-alauddin.ac.id/7780/

Bichi, A. A. (2016). Classical test theory: An introduction to linear modeling approach to test and item analysis. International Journal for Social Studies, 2(9), 27-33.

Farrokhi, F., \& Mahmoudi-Hamidabad, A. (2012). Rethinking convenience sampling: Defining quality criteria. Theory and Practice in Language Studies, 2(4), 784-792. https://doi.org/10.4304/tpls.2.4.784-792

Hamdi, S., Suganda, I. A., \& Hayati, N. (2018). Developing higher-order thinking skills (HOTS) test instrument using Lombok local cultures as contexts for junior secondary school mathematics. Research and Evaluation in Education, 4(2), 126135. https://doi.org/10.21831/reid.v4i2.22089

Herkusumo, A. P. (2011). Penyetaraan (equating) ujian akhir sekolah berstandar nasional (UASBN) dengan teori tes klasik [Equating National Standard School Final Examination (UASBN) With Classical Test Theory]. Jurnal Pendidikan dan Kebudayaan, 17(4), 455-471. https://doi.org/10.24832/jpnk.v17i4.41

Irianto, P. O., \& Febrianti, L. Y. (2017). Pentingnya penguasaan literasi bagi generasi muda dalam menghadapi MEA [The importance of literacy mastery for the young generation in facing the MEA]. Proceedings Education and Language International Conference, Center for International Language Development of Unissula, 640-647. http://jurnal.unissula.ac.id/index.php/ELIC/article/view/1282

Istiyono, E. (2018). Pengembangan instrumen penilaian dan analisis hasil belajar fisika dengan teori tes klasik dan modern [Development of assessment instruments and analysis of physics learning outcomes with classical and modern theories]. UNY Press.

Kaunang, D. F., Mantiri, J., \& Mangelep, N. O. (2018). Pengembangan soal literasi matematika berbasis kearifan lokal Minahasa untuk siswa SMP [Development of Minahasa local wisdom-based mathematical literacy questions for junior high school students]. Frontiers: Jurnal Sains dan Teknologi, 1(2), 223-230. https://doi.org/10.36412/frontiers/001035e1/agustus201801.11

Lange, J. (2003). Mathematics for literacy. In Quantitative Literacy: Why Numeracy 
Developing mathematical literacy test with context of Bugis-Makassar local ...

Matters for Schools and Colleges. (pp. 75-89). https://www.maa.org/sites/default/files/pdf/QL/WhyNumeracyMatters.pdf

Lestariningsih, \& Lutfianto, M. (2021). Development of mathematical literacy questions to support the mathematization of prospective teacher students. Jurnal Elemen, 7(1), 195-208. https://doi.org/10.29408/jel.v7i1.3003

Mardapi, D. (2017). Educational measurement, assessment, and evaluation (2nd ed.). Parama Publishing.

Mariyati, L. I., \& Affandi, G. R. (2016). Is the Nijmeegse Schoolbekwaamheids test (NST) appropriate to measure school readiness of early elementary school students in the Indonesian context? (Empirical analysis based on classical test theory). Scientific Journal of Applied Psychology, 4(2), 194-211.

Muslimin, T. P., \& Rahim, A. (2021). Etnomatematika permainan tradisional anak Makassar sebagai media pembelajaran geometri pada siswa SD [The Ethnomathematics of Traditional Makassar Children'sChildren's Games as Geometry Learning Media for Elementary School Students]. Pedagogy: Jurnal Pendidikan Matematika, 6(1), 22-32. https://doi.org/10.30605/pedagogy.v6i1.1195

OECD. (2010). PISA 2012 assessment and analytical framework: Mathematics, reading, science, problem solving and financial literacy. OECD Publishing. https://doi.org/10.1787/9789264190511-en

Pathuddin, H., \& Raehana, S. (2019). Etnomatematika: Makanan tradisional Bugis sebagai sumber belajar matematika [Ethnomathematics: Bugis traditional food as a source for learning mathematics]. MaPan: Jurnal Matematika dan Pembelajaran, 7(2), 307327. https://doi.org/10.24252/mapan.2019v7n2a10

Pranata, N., Nindiasari, H., \& Fatah, A. (2020). Efektivitas pendekatan kontekstual terhadap kemampuan literasi matematis siswa SMP berbasis karakter dan budaya lokal [The Effectiveness of Contextual Approach to Mathematical Literacy Ability of Junior High School Students Based on Character and Local Culture]. Wilangan: Jurnal Inovasi dan Riset Pendidikan Matematika, 1(3), 236-244. https://jurnal.untirta.ac.id/index.php/wilangan/article/view/9152

Pratiwi, I. (2019). Efek program PISA terhadap kurikulum di Indonesia [Effects of the PISA program on curriculum in Indonesia]. Jurnal Pendidikan dan Kebudayaan, 4(1), 51-71. https://doi.org/10.24832/jpnk.v4i1.1157

Retnawati, H. (2016). Analisis kuantitatif instrumen penelitian [Quantitative analysis of research instruments]. Parama Publishing.

Sa'idah, N., Yulistianti, H. D., \& Megawati, E. (2019). Analisis instrumen tes higher order thinking matematika SMP [Analysis of higher order thinking mathematics test instruments in junior high school]. Jurnal Pendidikan Matematika, 13(1), 41-54. https://doi.org/10.22342/jpm.13.1.6619.41-54

Saukiyah, S., Sunardi, \& Trapsilasiwi, D. (2017). Pengembangan soal literasi matematika berbasis budaya etnik Madura untuk siswa SMP/MTs [Development of Madura ethnic culture-based mathematical literacy questions for SMP/MTs Students]. KadikmA, 8(2), 166-175.

Supatmi. (2021). Peningkatan keterampilan guru dalam penyusunan soal pilihan ganda melalui pelatihan intensif [Improvement of Teacher Skills in the Preparation of Multiple Choice Questions through Intensive Training]. Jurnal Ilmiah Didaktika PGRI, 7(1), 17-22. http://didaktika.id/index.php/didaktika/article/view/84

Taskin, N., \& Tugrul, B. (2014). Investigating preschool teacher candidates'candidates' mathematics literacy self-sufficiency beliefs on various variables. Procedia - Social and Behavioral Sciences, 116, 3067-3071. 
https://doi.org/10.1016/j.sbspro.2014.01.708

Tegeh, I. M., \& Pudjawan, INJK (2015). Pengembangan buku ajar model penelitian pengembangan dengan model ADDIE [Development of the development research model textbook with the ADDIE model]. National Seminar on Innovative Research $I V$, 208-216. https://eproceeding.undiksha.ac.id/index.php/senari/article/download/507/352/

Totok, S. (2019). Pendidikan di Indonesia: belajar dari hasil PISA 2018 [Education in Indonesia: learning from PISA 2018 results]. Project Report. Badan Penelitian dan Pengembangan, Jakarta. http://repositori.kemdikbud.go.id/16742/

Vincent, W., \& Shanmugam, SKS (2020). The role of classical test theory to determine the quality of classroom teaching test items. Pedagogia: Jurnal Pendidikan, 9(1), 5-34. https://doi.org/10.21070/pedagogia.v9i1.123

Wartoni, W., \& Benjamin, P. I. (2020). Strategi pengembangan tes objektif (pilihan ganda) [Development strategy of objective test (multiple choice). Diegesis: Jurnal Teologi, 5(1), 1-8. http://sttbi.ac.id/journal/index.php/diegesis/article/view/55

Widodo, S. A., Ibrahim, I., Hidayat, W., Maarif, S., \& Sulistyowati, F. (2021). Development of mathematical problem solving tests on geometry for junior high school students. Jurnal Elemen, 7(1), 221-231. https://doi.org/10.29408/jel.v7i1.2973

Widodo, T., \& Solehudin, Z. (2021). Pengaruh social media marketing activities terhadap costumer response melalui mediasi brand equity pada e-wallet [Influence of social media marketing activities on customer response with mediation of brand equity in ewallet]. E-Proceeding of Management, 8(2), 987-994. https://openlibrarypublications.telkomuniversity.ac.id/index.php/management/arti cle/view/14769

Yansa, H., \& Retnawati, H. (2021). Identifikasi praktik dan hambatan guru dalam asesmen kognitif matematika di masa pandemi COVID-19 [Identification of Teacher Practices and Barriers in Mathematical Cognitive Assessment during the COVID-19 Pandemic]. Jurnal Elemen, 7(1), 84-97. https://doi.org/10.29408/jel.v7i1.2585 